\title{
Cadmium Phytoremediation Potential of Napiergrass Cultivated in Kyushu, Japan
}

\author{
Yasuyuki Ishii,, ${ }^{1}$ Kotomi Hamano, ${ }^{2}$ Dong-Jin Kang, ${ }^{3}$ Sachiko Idota, ${ }^{1}$ and Aya Nishiwaki ${ }^{1}$ \\ ${ }^{1}$ Department of Animal and Grassland Sciences, Faculty of Agriculture, University of Miyazaki, Miyazaki, \\ Miyazaki Prefecture 889-2192, Japan \\ ${ }^{2}$ Graduate School of Agriculture, University of Miyazaki, Miyazaki, Miyazaki Prefecture 889-2192, Japan \\ ${ }^{3}$ Teaching and Research Center for Bio-Coexistence, Hirosaki University, Goshogawara, Aomori 037-0202, Japan \\ Correspondence should be addressed to Yasuyuki Ishii; yishii@cc.miyazaki-u.ac.jp
}

Received 29 October 2015; Accepted 16 December 2015

Academic Editor: Ezio Ranieri

Copyright (C) 2015 Yasuyuki Ishii et al. This is an open access article distributed under the Creative Commons Attribution License, which permits unrestricted use, distribution, and reproduction in any medium, provided the original work is properly cited.

\begin{abstract}
Napiergrass (Pennisetum purpureum Schumach), a $\mathrm{C}_{4}$ tropical species, has been used for forage since it has high dry matter productivity, sustainability over several years in low-altitudinal sites of Kyushu, and little damage from serious pests. Recently, this grass has gained attention due to its potential as a bioethanol feedstock and for phytoremediation. Napiergrass cultivar Wruk Wona was grown as an annual crop in cadmium- (Cd-) contaminated soils under two cutting frequencies. Annual dry matter yield was not affected significantly by cutting frequency, but the concentration and uptake of $\mathrm{Cd}$ were higher when cut twice rather than only once, due to high Cd content of the herbage from the second cutting. Therefore, the soil Cd concentration was reduced by $4.6 \%$ when managed by cutting twice in a single year of Napiergrass cultivation.
\end{abstract}

\section{Introduction}

Cadmium (Cd), a heavy metal, poses risks to human health through the consumption of contaminated agricultural products. Since much arable land in Japan has been polluted by Cd, mainly from mining activity, the Japanese government reduced the critical contamination level of $\mathrm{Cd}$ in brown rice from 1.0 to $0.4 \mathrm{mg} \mathrm{kg}^{-1}$ in February, 2011, in conformance with the international WHO/FAO level [1]. The regulated level of $0.4 \mathrm{mg} \mathrm{kg}^{-1}$ for brown rice is higher than that for wheat and leafy vegetables $\left(0.2 \mathrm{mg} \mathrm{kg}^{-1}\right)$, which might indicate a future shift to make the regulated level for brown rice even more stringent. This new regulation should prompt remediation of Cd-contaminated land to increase the availability of arable land. Remediation techniques such as physical soil dressing and chemical washing with solvents have been applied to highly contaminated soils, such as old factory sites, but these conventional techniques have high cost, irrespective of purification efficiency. However, phytoremediation is suitable for arable lands over a wider area [2].
Napiergrass (Pennisetum purpureum Schumach), a $\mathrm{C}_{4}$ tropical forage species, produces high dry matter (DM) yield up to $33 \mathrm{tDM} \mathrm{ha}^{-1} \mathrm{yr}^{-1}$ in the first year of establishment in Kyushu, Japan [3]. The grass is resistant to heavy metalcontaminated substrates such as soil with a high $\mathrm{Cu}$ level $\left(50 \mathrm{mg} \mathrm{kg}^{-1}\right)$ in a pot trial [4] and in solutions containing stable cesium-133 $\left({ }^{133} \mathrm{Cs}\right)[5]$; although when grown on contaminated soil, it cannot be fed to livestock. Herbaceous species such as Miscanthus sinensis grown in paddy fields [6,7], Juncus subsecundus in soil culture [8], switchgrass in hydroponic culture [9], and several energy crops such as Arachis hypogaea, Brassica rapa, and Helianthus annuus in pots [10] absorb contaminating $\mathrm{Cd}$, while information is lacking on the Cd absorption ability of Napiergrass [11], despite its high DM production potential. In our previous study [11], Napiergrass $\mathrm{cv}$. Wruk Wona showed higher potential for removing $\mathrm{Cd}$ contamination than cv. Merkeron.

Cutting frequency significantly affects herbage DM yield, DM composition, and concentrations of structural carbohydrates and crude protein [12], and $\mathrm{Cd}$ concentration in Napiergrass was markedly higher in the second cutting than 
in the first, even though the second-cutting biomass was very limited [11].

Therefore, the objective of this study was to determine the phytoremediation potential of Napiergrass when cultured in Cd-contaminated hydroponic solutions and in field trials, as well as the management practices that optimize phytoremediation potential for $\mathrm{Cd}$.

\section{Materials and Methods}

2.1. Hydroponic Test of Napiergrass in Cd Added Solutions. Stem cuttings (1-2 nodes) of nursery plants of a tall-type of Napiergrass (cv. Merkeron, the most widespread throughout the region of Kyushu), which were grown in soil before the experiments, were transferred to $180 \mathrm{~L} \mathrm{Cd}$-free Hoagland nutrient solution. The solution contained $2 \mathrm{M} \mathrm{KNO}_{3}, 2 \mathrm{M}$ $\mathrm{Ca}\left(\mathrm{NO}_{3}\right)_{2}, 2 \mathrm{M} \mathrm{MgSO}_{4}, 1 \mathrm{M} \mathrm{NH}_{4} \mathrm{NO}_{3}$, and $1 \mathrm{M} \mathrm{KH}_{2} \mathrm{PO}_{4}$ as major elements and $462.5 \mathrm{mM} \mathrm{H}_{3} \mathrm{BO}_{3}, 91.45 \mathrm{mM} \mathrm{MnCl}_{2}$, $7.65 \mathrm{mM} \mathrm{ZnSO}_{4}, 3.195 \mathrm{mM} \mathrm{CuSO}_{4}$, and $4.96 \mathrm{mM} \mathrm{Na}_{2} \mathrm{MoO}_{4}$ as minor elements. The nursery plants were grown with air bubbled through the solution for 2 weeks in a glasshouse, without control over temperature, humidity, or day length, to allow shoots to emerge. The shoots were transferred to plastic containers ( $41 \mathrm{~cm}$ long, $31 \mathrm{~cm}$ wide, and $10 \mathrm{~cm}$ high) containing 3 levels of $\mathrm{Cd}(0,50$, or $100 \mu \mathrm{M} \mathrm{Cd})$, supplied in the form of $\mathrm{CdCl}_{2}$ in $4 \mathrm{~L} \mathrm{Hoagland} \mathrm{nutrient} \mathrm{solution} \mathrm{replaced} \mathrm{weekly}$ with air bubbled continuously through the solution in a hot summer season, from 23 June to 25 August, 2010. Containers with 9 plants were arranged in a randomized block design with 3 replications each for 3 randomly allocated treatments, for a total of 81 plants. Growth attributes of plant height and tiller number were measured every 2 weeks after treatment. To determine DM yield, aerial plant fractions were harvested from 3 plants per replication $5 \mathrm{~cm}$ above the water level at 2, 4 , and 8 weeks after treatment, which corresponded at 4,6 , and 10 weeks after planting in the solution media, respectively. The $\mathrm{Cd}$ concentration of aerial plant fractions, which were ground to pass through a $2-\mathrm{mm}$ mesh plastic screen, was determined without replication by Inductively Coupled Plasma Mass Spectrometry (ICP-MS, Agilent 7500ce, Agilent Technology Co. Ltd, USA) using microwave decomposition equipment (ETHOS One, Milestone General Co. Ltd., Kanagawa, Japan) after predigestion in $60 \% \mathrm{HNO}_{3}$.

2.2. Field Test of Napiergrass in Cd Contaminated Soil. Napiergrass cv. Wruk Wona was subjected to field trials in Cd-contaminated paddy fields (gray lowland soil) in 2011 in Kyushu, Japan, where the previous research was carried out in 2010 [11]. The source of Cd contamination in the soil was fallout dust from a neighboring zinc-refining plant $[13,14]$. The soil in these fields consists of clay loam (clay content $25 \%$, silt content $22 \%$, and sand content $53 \%$ ). The pH and the electric conductivity (EC) of the surface soil at $0-15 \mathrm{~cm}$ depth were examined by twin compact $\mathrm{pH}$ meter (B-212, Horiba Co. Ltd., Tokyo, Japan) and twin conductivity meter (B-173, Horiba Co. Ltd, Tokyo, Japan), respectively, on 5 June, 2010, and 23 November, 2010. The total C and total $\mathrm{N}$ content of the soil in these fields were reported to be $24 \mathrm{~g} \mathrm{~kg}^{-1}$ and $1.9 \mathrm{~g} \mathrm{~kg}^{-1}$, respectively, by Ibaraki et al. [14]. The crops cultivated before the previous [11] and present trials were sorghum as a summer crop and winter wheat as a winter crop.

After plowing, Napiergrass was vegetatively transplanted using stem cuttings at 2 plants $\mathrm{m}^{-2}$ with $30 \mathrm{~m}^{2}$ per plot on 7 May, 2011, and supplied with a basal application of slowreleasing LP compound fertilizer with $37.6 \mathrm{~g} \mathrm{~m}^{-2}$ each of $\mathrm{N}$, $\mathrm{P}_{2} \mathrm{O}_{5}$, and $\mathrm{K}_{2} \mathrm{O}$ per season, which are levels suitable for supporting high biomass of this species [15]. The planting area was covered with biodegradable mulch film to suppress growth and Cd accumulation of weedy species, since the growth of Napiergrass is retarded severely by the invasion of weeds [16]. Plots were arranged in a randomized split-plot design with 6 replications, each containing 2 cutting frequencies (once or twice a year), for a total of 12 plots.

The growth attributes of plant height, tiller number, fresh weight, and DM of aerial fractions were determined for 2 plants per plot (total of 12 plants per treatment) at monthly intervals in the growing season on 11 June, 9 July, 5 August, 14 September, 15 October, and 26 October, 2011 (35, 63, 90, 130, 161, and 172 days after planting, resp.). Plants were harvested $10 \mathrm{~cm}$ above the ground and divided into fractions: leaf blade, stem inclusive of leaf sheath, and dead leaves. For treatments with two cuttings, the first cutting was on 14 September and the second was on 26 October, whereas, for single cuttings, plants were cut on 26 October. Plants were harvested into several fractions, such as aerial parts of cuts $10 \mathrm{~cm}$ above the ground, stubble $0-10 \mathrm{~cm}$ above the ground, underground stem parts, and roots in an area of $50 \mathrm{~cm} \times 50 \mathrm{~cm}$ and $20 \mathrm{~cm}$ depth. On 26 October, aerial parts and stubble were divided into mother tiller and delayed tillers for the single-cutting treatment, and stubble was divided into mother tiller and tillers formed during regrowth in the two-cutting treatment. After measuring fresh weight of plant samples, subsamples (around 300-400 g) of all plant fractions were dried at $70^{\circ} \mathrm{C}$ for $72 \mathrm{~h}$ in a ventilating oven for DM determination. DM yield of plants was calculated by plant fresh weight, multiplied by percentage of DM, and plant density $\left(2\right.$ plants $\left.\mathrm{m}^{-2}\right)$. The $\mathrm{Cd}$ concentration of ground plant samples was determined using the same procedure as in 2.1 for the hydroponic test.

Soils were sampled for $0-15 \mathrm{~cm}$ layer with 3 replications on 29 April, 14 September, and 26 October, 2011 (8 days before planting, and 130 and 172 days after planting, resp.), for both once- and twice-cutting plots. Soil Cd concentration was determined by atomic absorption spectroscopy (AA6200 , Shimadzu Corporation, Kyoto, Japan) at $2288 \AA$ of wavelength after predigested with $5 \%$ hydrochloric acid solution gently shaking at $30^{\circ} \mathrm{C}$ for 1 hour and filtrated [17].

2.3. Statistical Analysis. One-way analysis of variance was carried out using Excel Statistics 2010 software (Social Information Service, Tokyo, Japan). Differences in means were evaluated using Fisher's least significant difference (LSD) test at the $5 \%$ level.

\section{Results and Discussion}

3.1. Culture of Napiergrass in Cd Solutions. Dry weight of the aerial herbage did not differ significantly at concentrations of 50 and $100 \mu \mathrm{M} \mathrm{Cd}(P>0.05)$ at 2,4 , or 8 weeks after 
TABLE 1: Changes in cadmium (Cd) concentration and uptake of Napiergrass plants grown in Cd-containing hydroponic conditions in 2010.

\begin{tabular}{|c|c|c|c|}
\hline \multirow{2}{*}{ Parameter } & \multicolumn{3}{|c|}{ Cd solution $(\mu \mathrm{M})$} \\
\hline & 0 & 50 & 100 \\
\hline \multicolumn{4}{|l|}{ Plant dry weight (g/plant) } \\
\hline 2 weeks after treatment & $2.11 \pm 2.09$ & $1.29 \pm 0.58$ & $0.64 \pm 0.31$ \\
\hline 4 weeks after treatment & $5.84 \pm 9.98$ & $0.69 \pm 0.74$ & $2.13 \pm 1.63$ \\
\hline 8 weeks after treatment & $45.19^{\mathrm{a}} \pm 37.44$ & $4.03^{b} \pm 3.14$ & $3.39^{\mathrm{b}} \pm 1.15$ \\
\hline \multicolumn{4}{|l|}{ Cd concentration (mg/kg) } \\
\hline 2 weeks after treatment & 0 & 41 & 42 \\
\hline 4 weeks after treatment & 0 & 41 & 46 \\
\hline 8 weeks after treatment & 0.3 & 31 & 58 \\
\hline \multicolumn{4}{|l|}{ Cd uptake (g/plant) } \\
\hline 2 weeks after treatment & $0^{\mathrm{b}}$ & $0.053^{\mathrm{a}} \pm 0.024$ & $0.027^{\mathrm{a}} \pm 0.013$ \\
\hline 4 weeks after treatment & 0 & $0.028 \pm 0.030$ & $0.098 \pm 0.075$ \\
\hline 8 weeks after treatment & $0.014^{\mathrm{b}} \pm 0.011$ & $0.125^{\mathrm{a}} \pm 0.097$ & $0.196^{\mathrm{a}} \pm 0.066$ \\
\hline
\end{tabular}

Means in the same row followed by the same letter were not significantly different at $P<0.05$ based on LSD test.

treatment, while it was significantly lower $(P<0.05)$ in both $\mathrm{Cd}$ treatments than in the control $(0 \mu \mathrm{M} \mathrm{Cd})$ at any time after treatment. The $\mathrm{Cd}$ concentration in the aerial plant fractions tended to be higher in Cd treatments than in the control, where detection of trace $\mathrm{Cd} 8$ weeks after treatment might be due to contamination from the Cd treatments. In contrast, a nonsignificant difference was observed between Cd concentrations (50 and $100 \mu \mathrm{M} \mathrm{Cd}$ ) at 2, 4, and 8 weeks after treatment. Therefore, $\mathrm{Cd}$ accumulation in the aerial part tended to be higher at higher Cd concentration $(100 \mu \mathrm{M})$, even though the difference between $\mathrm{Cd}$ concentrations was not significant and tended to increase with growth at 4 and 8 weeks after treatment (Table 1). The growth and Cd concentration of Napiergrass indicated that this species does not show any dose-dependent response to $\mathrm{Cd}$, an effect also observed in Miscanthus [7]. The highest Cd uptake, occurring at the $100 \mu \mathrm{M} \mathrm{Cd}$ dose, suggests that this species may adapt to soils contaminated with significant levels of Cd. Even under hydroponic culture, Napiergrass was grown by bubbling with air both before and after Cd treatment to prevent reducing conditions in the solution. Reducing conditions would allow binding of $\mathrm{Cd}$ to divalent anions $\left(\mathrm{S}^{-}\right)$, forming insoluble $\mathrm{Cd}$ sulfide (CdS) [14].

3.2. Response of Napiergrass to Cd-Contaminated Soils. The soil $\mathrm{pH}$ was 5.21 and the electrical conductivity (EC) was $7.18 \mathrm{mS} \mathrm{m}^{-1}$ on 5 June, 2010 , and the values were, respectively, 5.56 and $3.69 \mathrm{mS} \mathrm{m}^{-1}$ on 23 November, 2010. Soil adsorption capacity for $\mathrm{Cd}$ increases with higher $\mathrm{EC}$ and $\mathrm{pH}$, demonstrated by an increase in the capacity in amended cow manure due to higher $\mathrm{pH}$ [18]. In the present study, the soil chemical properties were $\mathrm{pH}$ values below 7 and $\mathrm{EC}$ values were low, which have been suggested to favor suppression of adsorption of Cd [18]. Plant height and tiller density changed similarly among treatments up to 14 September. The rapid increase from May to June was due to vegetative growth. This was followed by a marked decrease up to the early August, due to both self-thinning of tillers and a slower emergence of tillers resulting from an increase in light intensity at

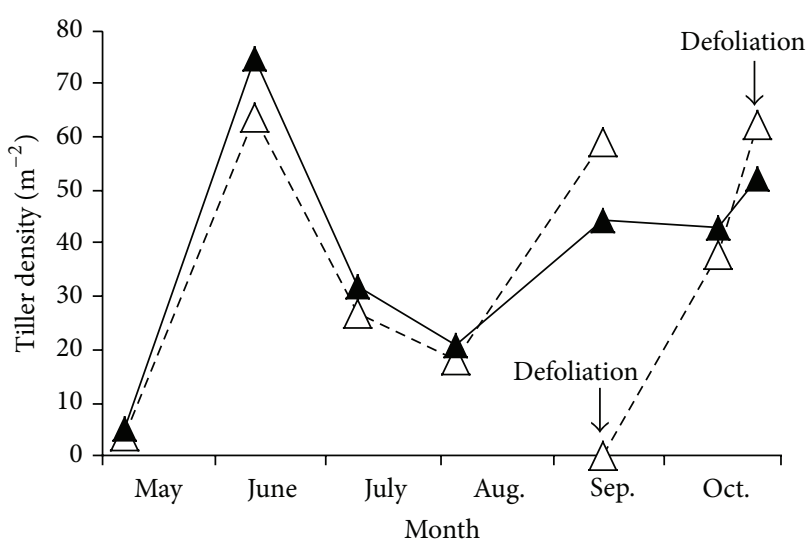

FIGURE 1: Changes in tiller density of Napiergrass after a single cutting $(\mathbf{\Delta})$ and after two cuttings $(\triangle)$.

the bottom of the canopy due to rapid stem elongation. However, in the two-cutting plot after the first cutting on 14 September, tiller density increased as rapidly as in the vegetative growth phase so that the density became similar for both treatments on 26 October. The increase in tiller density after 14 September in the single-cutting plot resulted from the continued emergence of delayed tillers (Figure 1).

DM tended to be higher in the two-cutting than the single-cutting plot on 14 September, 2011, possibly due to drought stress in the elevated area of the single-cutting plot (Figure 2). However, plant DM in the single-cutting plot recovered by 26 October (Figure 2) due to the emergence of delayed tillers after sufficient precipitation in mid-September (Figure 1). Regrowth DM yield in the two-cutting plot was severely limited on 26 October, and thus annual DM yield did not differ significantly between the treatments. Underground stem DM yield was $8-10 \%$ of total plant DM yield on the two monitored dates in the single-cutting plot as well as for the first cutting of plants in the two-cutting plot on 14 September, while the percentage increased to $55 \%$ in the two-cutting plot on 26 October (Figure 2). A soil Cd concentration of 


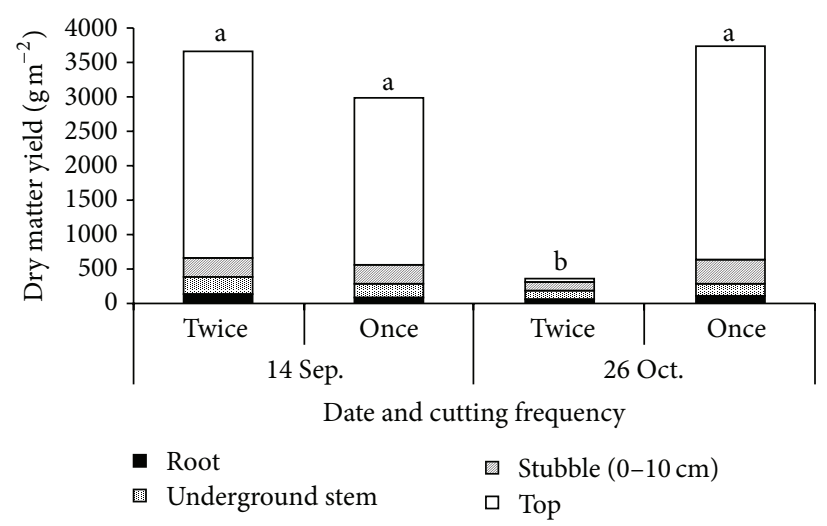

Figure 2: Changes in DM yield of Napiergrass after a single cutting (once) and after two cuttings (twice). Figures with the same letter were not significantly different at $P<0.05$ based on LSD test.

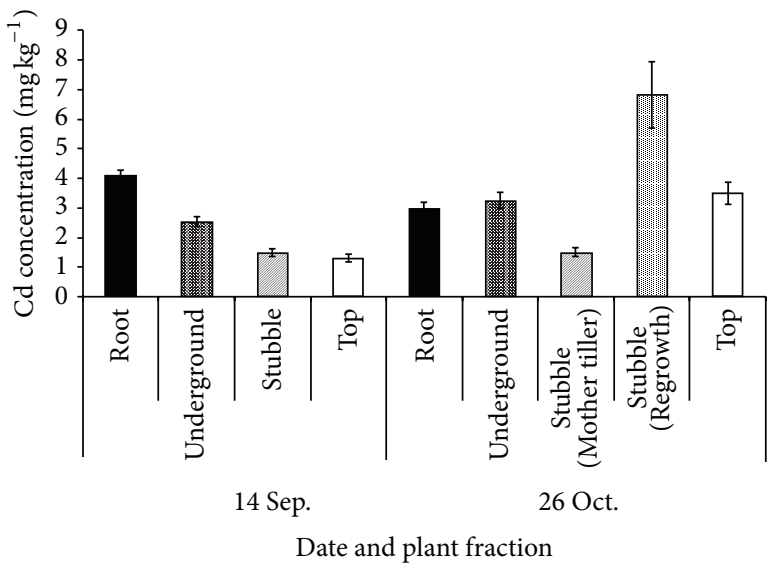

(a)

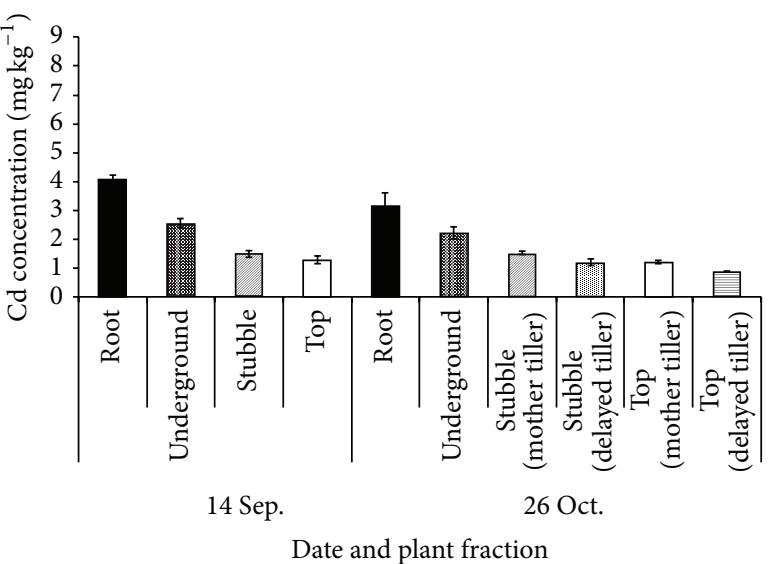

(b)

Figure 3: Cadmium (Cd) concentration in several plant fractions of Napiergrass after two cuttings (a) and after a single cutting (b). Mean \pm standard deviation $(n=3)$.

$1.45 \mathrm{mg} \mathrm{kg}^{-1}$, which is equivalent to $15 \mu \mathrm{M} \mathrm{Cd}$, did not cause any observable inhibition of tall-type Napiergrass growth in the heavy clay soil examined, which was consistent with the absence of a significant effect on growth of barley in pots by adding $10 \mathrm{mM} \mathrm{Cd}$ to the soil [19].

Plant Cd concentration was highest in the roots, followed by underground stems and stubble, with the lowest concentration of $1.29 \mathrm{mg} \mathrm{kg}^{-1}$ in top parts being similar for both treatments on 14 September (Figures 3(a) and 3(b)). The Cd concentration was similar across plant fractions for the single-cutting plot on 26 October and 14 September, even after the appearance of delayed tillers (Figure 3(b)). However, in the two-cutting plot on 26 October, the $\mathrm{Cd}$ concentration in the stubble of regrowth tillers was highest, above $6 \mathrm{mg} \mathrm{kg}^{-1}$, followed by the top parts at around $3 \mathrm{mg} \mathrm{kg}^{-1}$, which was significantly higher than that in the stubble of mother tillers (Figure 3(a)).

The tendency for $\mathrm{Cd}$ concentration to decrease from roots to the harvested parts of aerial tillers was similar to Miscanthus [7], which presumably reflects the translocation of $\mathrm{Cd}$ from roots to aboveground parts. Indica rice (Oryza sativa L.) cv. Moretsu accumulated a higher Cd concentration than the cultivar IR-8 [14], showing potential as a Cd phytoextractor for paddy fields. Napiergrass accumulated Cd in the aboveground parts at concentrations ranging from 1.30 to $7.05 \mathrm{mg} \mathrm{kg}^{-1}$ in the two-cutting plot on 26 October (Figure 3(a)), which was lower than that in indica rice cultivated in Cd-polluted lowlands, which ranged from 31.4 to $41.0 \mathrm{mg} \mathrm{kg}^{-1}$ [14]. However, the yield of Napiergrass, which is in the range of 3000 to $4000 \mathrm{~g} \mathrm{DM} \mathrm{m}^{-2}$ under proper transplanting and infrequent cutting in southern Kyushu, even in the year of establishment $[3,12]$, was considerably higher than indica rice, ranging from 1100 to $1260 \mathrm{~g} \mathrm{DM} \mathrm{m}^{-2}$ [14]. Therefore, Napiergrass is a potential phytoextractor for Cdpolluted lowlands in addition to being useful as a biofuel feedstuff due to its high DM productivity [3]. Napiergrass needs proper fertilization [15] and weeding [16] management combined with genotype selection [20] to exhibit its potential for $\mathrm{Cd}$ phytoremediation. Proper organic and inorganic fertilization is needed for Cd phytoremediation; for example, amendment of soil with quail litter biochar increased the physic nut yield and reduced $\mathrm{Cd}$ residue in the plants due 


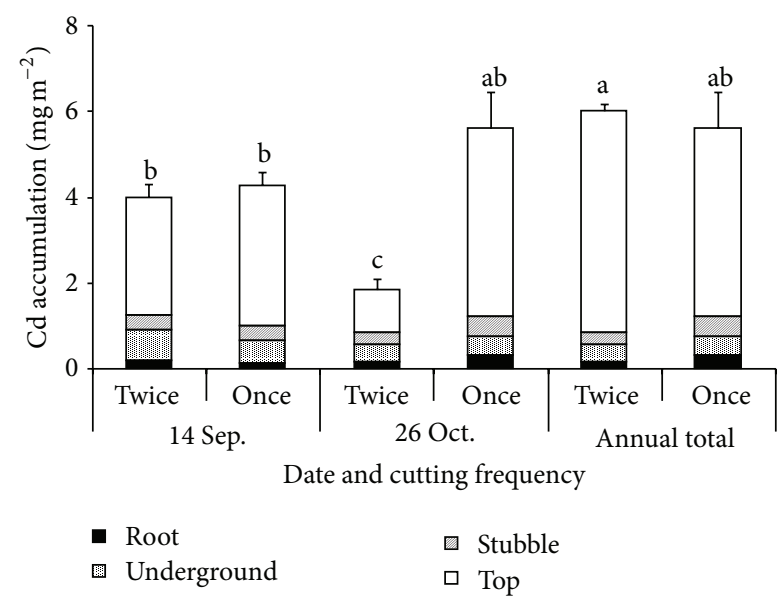

Figure 4: Cadmium (Cd) accumulation of Napiergrass following the first and second cuts from plots after a single (Once) or two cuttings (Twice). Mean \pm standard deviation $(n=3)$. Figures with the same letter were not significantly different at $P<0.05$ based on LSD test.

to a reduction in bioavailability of $\mathrm{Cd}$, resulting in decreased potential to remediate Cd-contaminated soil [21]. In contrast, the increase in alfalfa plant biomass as well as uptake of $\mathrm{Cd}$ was dependent on the supply of nitrate in pots of $\mathrm{Cd}$ amended soil [22].

Annual total plant $\mathrm{Cd}$ accumulation tended to be $7 \%$ higher in the two-cutting plot than in the single-cutting plot (Figure 4). The Cd concentration within the first $20 \mathrm{~cm}$ of soil depth decreased $4.6 \%$ from 29 April to 26 October in the twocutting plots, compared to $2.6 \%$ for the single-cutting plots in a single growing season. The remaining $\mathrm{Cd}$ might remain in hypogeal parts such as roots and underground stems and the aboveground stubble left by cutting stems $10 \mathrm{~cm}$ above the ground. The stubble had higher absolute $\mathrm{Cd}$ concentrations than the aerial part of Miscanthus [7].

In soils, $\mathrm{Cd}$ remains in exchangeable, dilute-acid extractable, and organically bound forms, with the exchangeable form making up a few percent of the total [1]. Soil Cd concentrations on 29 April (8 days before planting) were 1.47 and $1.30 \mathrm{mg} \mathrm{kg}^{-1}$ in once- and twice-cutting plot, respectively, and those on 26 October (second harvest) were 1.40 and $1.27 \mathrm{mg} \mathrm{kg}^{-1}$ in once- and twice-cutting plot, respectively (Figure 5). Therefore, a soil Cd concentration was reduced by $4.6 \%$ and $2.6 \%$ when managed by cutting twice and once, respectively, in a single year of Napiergrass cultivation (Figure 5), and that of $1.47 \mathrm{mg} \mathrm{kg}^{-1}$, which is almost equivalent to $15 \mu \mathrm{M} \mathrm{Cd}$, did not cause any observable inhibition of tall-type Napiergrass growth in the heavy clay soil that was examined.

\section{Conclusions}

Related to its phytoremediation activity, growth of tall-type Napiergrass cultured in Hoagland solution was inhibited by $\mathrm{Cd}$, while the maximum Cd uptake for phytoextraction was achieved at $100 \mu \mathrm{M} \mathrm{Cd}$, the highest level tested. In

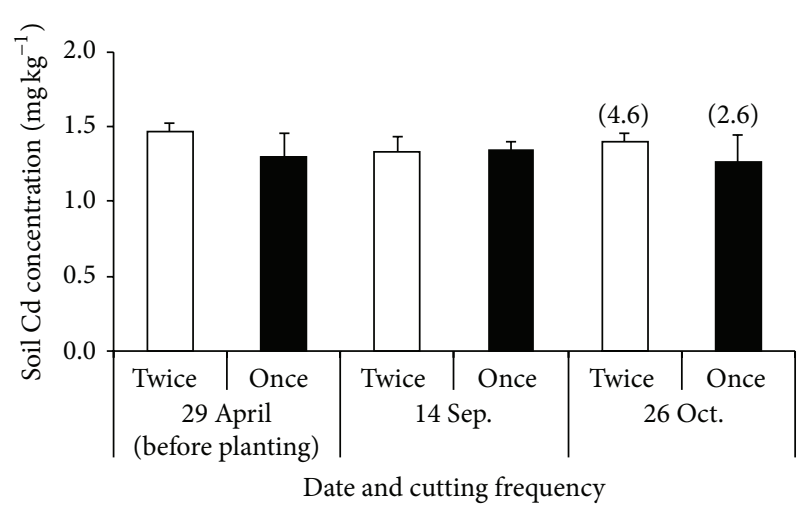

FIGURE 5: Cadmium (Cd) concentration of soils in $0-15 \mathrm{~cm}$ depth before planting and following the first and second cuts from plots after a single (Once) or two cuttings (Twice). Mean \pm standard deviation $(n=3)$. Figures with parenthesis show the decreasing percentage from $\mathrm{Cd}$ concentration before planting.

Cd-contaminated lowland fields, where soil Cd concentration was equivalent to $15 \mu \mathrm{M}$, tall-type Napiergrass growth was as healthy as in Cd-free soils, and Cd uptake was higher in plots cut twice than in those cut once due to higher $\mathrm{Cd}$ concentration in plants showing regrowth, even though it was limited. Thus, soil Cd concentration was reduced by $4.6 \%$ following two harvests in a single growing season, suggesting that Napiergrass is a potential Cd phytoextractor.

\section{Conflict of Interests}

It is declared that the authors have neither any conflict of interests nor financial gain for this paper.

\section{Acknowledgment}

A part of this study was supported by JSPS Grant-in-Aid for Scientific Research (C), Grant no. 25450025.

\section{References}

[1] T. Makino, K. Sugahara, Y. Sakurai et al., "Remediation of cadmium contamination in paddy soils by washing with chemicals: selection of washing chemicals," Environmental Pollution, vol. 144, no. 1, pp. 2-10, 2006.

[2] T. Arao, S. Ishikawa, M. Murakami, K. Abe, Y. Maejima, and T. Makino, "Heavy metal contamination of agricultural soil and countermeasures in Japan," Paddy and Water Environment, vol. 8, no. 3, pp. 247-257, 2010.

[3] L. Khairani, Y. Ishii, S. Idota, R. F. Utamy, and A. Nishiwaki, "Variation in growth attributes, dry matter yield and quality among 6 genotypes of napier grass used for biomass in year of establishment in Southern Kyushu, Japan," Asian Journal of Agricultural Research, vol. 7, no. 1, pp. 15-25, 2013.

[4] X. Liu, Y. Shen, L. Lou, C. Ding, and Q. Cai, “Copper tolerance of the biomass crops Elephant grass (Pennisetum purpureum Schumach), Vetiver grass (Vetiveria zizanioides) and the upland reed (Phragmites australis) in soil culture," Biotechnology Advances, vol. 27, no. 5, pp. 633-640, 2009. 
[5] D. J. Kang, Y.-J. Seo, T. Saito, H. Suzuki, and Y. Ishii, "Uptake and translocation of cesium-133 in napiergrass (Pennisetum purpureum Schum.) under hydroponic conditions," Ecotoxicology and Environmental Safety, vol. 82, pp. 122-126, 2012.

[6] I. Arduini, A. Masoni, L. Ercoli, and M. Mariotti, "Growth and cadmium uptake of Miscanthus sinensis as affected by cadmium," Agricoltura Mediterranea, vol. 133, no. 1, pp. 169-178, 2003.

[7] I. Arduini, L. Ercoli, M. Mariotti, and A. Masoni, "Response of miscanthus to toxic cadmium applications during the period of maximum growth," Environmental and Experimental Botany, vol. 55, no. 1-2, pp. 29-40, 2006.

[8] Z. Zhang, Z. Rengel, H. Chang, K. Meney, L. Pantelic, and R. Tomanovic, "Phytoremediation potential of Juncus subsecundus in soils contaminated with cadmium and Polynuclear Aromatic Hydrocarbons (PAHs)," Geoderma, vol. 175-176, no. 1, pp. 1-8, 2012.

[9] B.-C. Chen, H.-Y. Lai, and K.-W. Juang, "Model evaluation of plant metal content and biomass yield for the phytoextraction of heavy metals by switchgrass," Ecotoxicology and Environmental Safety, vol. 80, no. 1, pp. 393-400, 2012.

[10] G. Shi and Q. Cai, "Cadmium tolerance and accumulation in eight potential energy crops," Biotechnology Advances, vol. 27, no. 5, pp. 555-561, 2009.

[11] Y. Ishii, K. Hamano, D. J. Kang et al., " $\mathrm{C}_{4}$-Napier grass cultivation for cadmium phytoremediation activity and organic livestock farming in Kyushu, Japan," Journal of Agricultural Science and Technology A, vol. 3, no. 4, pp. 321-330, 2013.

[12] M. Mukhtar, Y. Ishii, S. Tudsri, S. Idota, and T. Sonoda, "Dry matter productivity and overwintering ability of the dwarf and normal napiergrasses as affected by the planting density and cutting frequency," Plant Production Science, vol. 6, no. 1, pp. 65-73, 2003.

[13] T. Ibaraki, K. Kadoshige, and M. Murakami, "Evaluation of extraction methods for plant-available soil cadmium to wheat by several extraction methods in cadmium-polluted paddy field," Soil Science and Plant Nutrition, vol. 51, no. 6, pp. 893898, 2005.

[14] T. Ibaraki, N. Kuroyanagi, and M. Murakami, "Practical phytoextraction in cadmium-polluted paddy fields using a high cadmium accumulating rice plant cultured by early drainage of irrigation water," Soil Science and Plant Nutrition, vol. 55, no. 3, pp. 421-427, 2009.

[15] A. Wadi, Y. Ishii, and S. Idota, "Effects of the level of fertilizer input on dry matter productivity of napiergrass and kinggrass," Grassland Science, vol. 48, no. 4, pp. 490-503, 2003.

[16] R. F. Utamy, Y. Ishii, S. Idota, and L. Khairani, "Effect of weed control management on herbage yield, quality and wintering ability in the established dwarf napiergrass (Pennisetum purpureum Schumach)," Journal of Warm Regional Society of Animal Science, Japan, vol. 55, no. 1, pp. 17-26, 2012.

[17] Ministry of Agriculture and Forestry, Ordinance of the Ministry of Agriculture and Forestry, Japan, no. 47 of 1971, 1971, http:// www.lawdata.org/law/htmldata/S46/S46F00601000047.html.

[18] M. Chorom, R. M. Karkaragh, B. Kaviani, and Y. K. Kalkhajeh, "Monometal and competitive adsorption of $\mathrm{Cd}, \mathrm{Ni}$, and $\mathrm{Zn}$ in soil treated with different contents of cow manure," Applied and Environmental Soil Science, vol. 2013, Article ID 510278, 8 pages, 2013.

[19] B. B. M. Sridhar, F. X. Han, S. V. Diehl, D. L. Monts, and Y. $\mathrm{Su}$, "Effects of $\mathrm{Zn}$ and $\mathrm{Cd}$ accumulation on structural and physiological characteristics of barley plants," Brazilian Journal of Plant Physiology, vol. 19, no. 1, pp. 15-22, 2007.

[20] M. J. Williams and W. W. Hanna, "Performance and nutritive quality of dwarf and semi-dwarf elephantgrass genotypes in the south-eastern USA," Tropical Grasslands, vol. 29, no. 2, pp. 122127, 1995.

[21] T. Suppadit, V. Kitikoon, A. Phubphol, and P. Neumnoi, "Effect of quail litter biochar on productivity of four new physic nut varieties planted in cadmium-contaminated soil," Chilean Journal of Agricultural Research, vol. 72, no. 1, pp. 125-132, 2012.

[22] S. Hattab, S. Hattab, H. Boussetta, and M. Banni, "Influence of nitrate fertilization on Cd uptake and oxidative stress parameters in alfalfa plants cultivated in presence of Cd," Journal of Soil Science and Plant Nutrition, vol. 14, no. 1, pp. 89-99, 2014. 

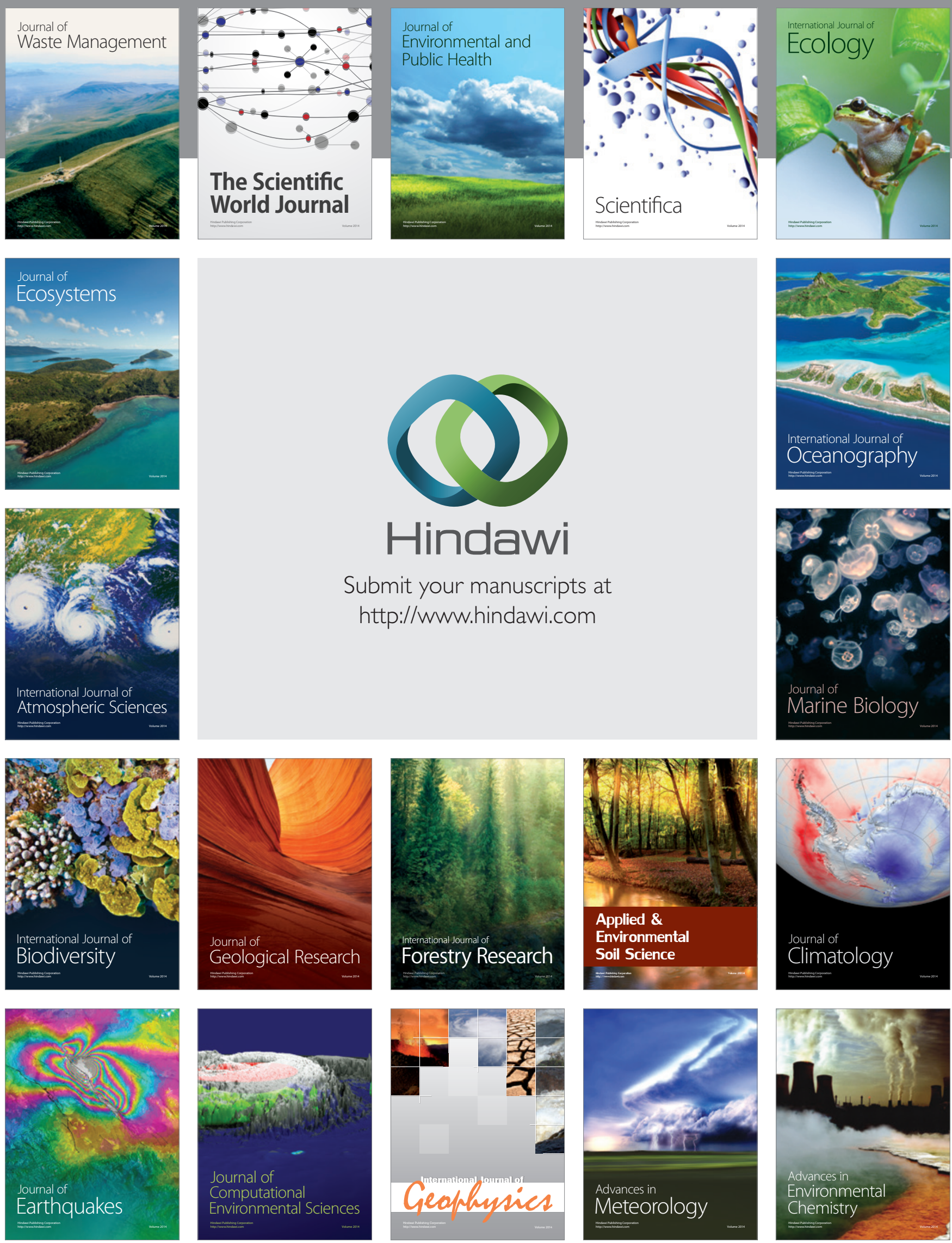